\title{
Tinjauan Asas Ar-Ridha Terhadap Akad Pembiayaan Murabahah Pada Perbankan Mandiri Syariah Cabang Sorong
}

\author{
H. Muhammad Ali \\ Fakultas Hukum, Universitas Muhammadiyah Sorong \\ Email : Mulisidiq@yahoo.co.id
}

\begin{abstract}
Abstrak
Penelitian ini bertujuan untuk mengetahui, menganalisis dan menjelaskan mekanisme pembiayaan murabaha kepada nasabah bank mandiri syariah cabang sorong dengn landasan Ar-ridha atau kerelaan kedua belah pihak antara nasabah sebagai pengguna dana dan pihak bank sebagai pemberi dana dengan akad pembiayaan Murabahah.

Berdasarkan penelitian dan Pembahasan, maka penulis menyimpulkan Akad merupakan cerminan telah terjadinya hubungan dan kesepakatan antara pihak bank dan pihak nasabah untuk melakukan suatu kegiatan ekonomi. Kegiatan ekonomi dalam prinsip syariah menggunakan prinsip kemitraan sehingga lebih mengutamakan hubungan yang harmonis antara kedua belah pihak. Akad yang konsekuensi pertanggungjawabannya tidak hanya didunia tetapi juga diakhirat sehingga mempunyai akibat yang sangat berat. Pelaksanaan akad murabahah dalam melakukan kegiatan pembiayaan untuk pembelian sutau obyek tertentu dengan disepakati para pihak berserta mark-up/margin yang telah disepakati. Yang mana untuk memudahkan transaksi bank membuat suatu kontrak baku sehingga pihak bank tinggal membubuhkan tanda-tangan untuk persetujuan kontrak tersebut. Telah menggambarakan prinsip syariah yaitu ar-ridha karena diberikan keleluasaan pihak nasabah untuk menyetujui atau menolak perjanjian tersebut atau adanya pilihan bebas kepada pihak nasabah.
\end{abstract}

Kata Kunci : Perbank Syariah; Defenisi Akad Ar-Ridha; Pembiayaan Murabahah

\section{PENDAHULUAN}

Pembangunan nasional yang dilaksanakan oleh Bangsa Indonesia selama ini adalah merupakan upaya pembangunan yang berkesinambungan dalam rangka mewujudkan cita-cita masyarakat yang adil dan makmur berdasarkan Pancasila dan Undang-Undang Dasar Negara Republik Indonesia 1945. Untuk mencapai tujuan tersebut pelaksanaan pembangunan nasional tentunya harus senantiasa memperhatikan keserasian, keselarasan, dan keseimbangan berbagai unsur pembangunan, termaksud dibidang ekonomi dan keuangan. 
Lembaga perbankan merupakan inti dari sistem keuangan setiap negara. Bank adalah lembaga keuangan yang menjadi tempat bagi orang perorangan, badan-badan swasta, badan-badan usaha milik negara, bahkan lembaga pemerintah yang menyimpan dana-dana yang dimilikinya. Lembaga perbankan mempunyai nilai strategis dalam perekonomian suatu negara, karena peranannya sebagai perantara pihak-pihak yang mempunyai kelebihan dana (surplus of fund) dengan pihak yang kekurangan dan memerlukan dana (lack of fund). Dengan demikian perbankan akan bergerak dalam bidang pembiayaan, jual beli dan berbagai jasa yang diberikan untuk melancarkan semua sektor perekonomian.

Eksistensi perbankan syariah memberikan angin segar kepada perbankan di Indonesia setelah terjadinya krisis ekonomi 1997-1998 sehingga pemerintah membuat regulasi khusus tentang perbankan syariah yaitu Undang-Undang Nomor 21 Tahun 2008 tentang Perbankan Syariah. Tentunya untuk mengenalkan produk perbankan syariah kepada masyarakat secara luas maka pemerintah memperbolehkan bank konvensional melakukan kegiatan-kegiatan perbankan syariah dengan membuka cabang-cabang baru dengan mekanisme dan kegiatan usaha Syariah atau biasa dikenal dengan islamic window.

Data yang dirilis oleh Bank Indonesia, Pada tahun 2011 market share perbankan syaraih terhadap perbankan nasional telah mencapai sekitar 3,8\%. Salah satu skema pembiayaan yang mendominasi penyaluran dana pada masyarakat adalah melalui akad murabahah berjumlah sekitar $42,42 \%$ dari total penyaluran dana pada periode 2010 sampai 2011. Dominasi pembiayaan murabahah dalam perbankan syariah karena memiliki banyak kesamaan dengan pola pembiayaan kredit sehingga mudah diterima masyarakat. Murabahah adalah perjanjian jual beli barang pada harga asal dengan tambahan keuntungan/margin yang disepakati. Dengan kata lain, nasabah dapat membeli produk yang dibutuhkannya tetapi tidak mampu membayar sekaligus sehingga dilakukan penangguhan pembayaran. Meskipun, nasabah harus membayar lebih tinggi dari harga pembelian asli. Ciri khas murabahah adalah penjual 
mengungkapkan biaya yang sebenarnya dan meminta keuntungan dalam bentuk persentase dari biaya yang dikeluarkan. Dalam Islam, murabahah merupakan salah satu bentuk jual beli yang bersifat amanah. Jual beli bersifat amanah dapat diartikan sebagai jual beli transparan, yaitu penjual mempunyai keharusan untuk memberitahukan harga pokoknya dan keuntungan yang diambil dari barang yang dijual tersebut kepada pembeli secara jujur. Ketidakjujuran dalam melakukan transaksi jual beli bersifat amanah termaksud di dalamnya melakukan tindakan berupa diam semata maka dapat diartikan sebagai salah satu bentuk penipuan.

Prosedur pemberian akad Murabahah dimulai dengan informasi yang diberikan oleh pihak Bank Syariah melalui brosur-brosur yang ada disediakan secara gratis di kantor-kantor Bank Syariah setempat atau brosur yang dibuat oleh penjual barang, para developer toko-toko yang menjual barang yang dapat dibeli secara angsuran. Pada brosur tersebut dikemukakan bahwa konsumen dapat membeli rumah atau barang tersebut dengan pembayaran secara angsuran di Bank Syariah. Penawaran bisa juga dilakukan oleh penjual barang dengan mendatangi kantor, perusahaan atau tempat tempat kerja lain yang membutuhkan alat elektronik, laptop misalnya atau berbagai cara yang lain. Kalau ada calon nasabah yang berminat, maka bisa meminta informasi lebih detail kepada bagian pemasaran pihak penjual barang yang nanti akan dibeli oleh pihak bank dan/atau costumer service Bank Syariah. Kemudian calon nasabah diwajibkan untuk mengisi application-form yang telah tersedia; setelah disepakati margin keuntungannya, ditandatanganilah akad Murabahah yang disediakan juga oleh pihak Bank Syariah. Jadi semua form telah tersedia, walaupun form tersebut ada bagian yang kosong yang kemudian diisi oleh kedua pihak dari hasil kesepakatan. Pemberian pembiayaan dengan akad murabahah yang telah dibakukan/ yang dibuat sepihak oleh pihak perbankan, apakah telah memenuhi asas ar-ridha.; (1) Berdasarkan uraian latar belakang di atas, yang menitik beratkan pada pembiayaan murabahah sehingga permasalahan yang dapat penulis 
ketengahkan yaitu Bagaimanakah Penerapan Asas Ar-Ridha terhadap Akad Pembiayaan Murabahah dalam Perbankan Syariah?

\section{PEMBAHASAN}

\section{Analisis Asas Ar-Ridha Terhadap Akad Pembiayaan Murabahah dalam Perbankan Syariah.}

Sistem perbankan syariah sebagian dari konsep ekonomi Islam ke dalam lingkungan ekonomi. Oleh karena itu, perbankan syariah tidak hanya dituntut untuk menghasilkan keuntungan melalui setiap transaksi komersial saja, tetapi juga dituntut untuk mengimplementasikan nilai-nilai syariah yang sesuai dengan al-qur'an dan al hadist. Asas merupakan ruh dari akad, sehingga akad yang dibuat tidak boleh bertentangan dengan asas berlaku. Hukum Islam juga mengenal asas-asas hukum perjanjian. Adapun asas-asas itu adalah sebagai berikut; (a) Al-Hurriyah (kebebasan) Asas ini merupakan prinsip dasar dalam hukum perjanjian Islam, dalam artian para pihak bebas membuat suatu perjanjian atau akad (freedom of making contract). Bebas dalam menentukan obyek perjanjian dan bebas menentukan dengan siapa ia akan membuat perjanjian, serta bebas menentukan bagaimana cara menentukan penyelesaian sengketa jika terjadi dikemudian hari.

Asas kebebasan berkontak di dalam hukum islam dibatasi oleh ketentuan syariah Islam. Dalam membuat perjanjian ini tidak boleh ada unsur paksaan, kekhilafan dan penipuan. Dasar hukum mengenai asas ini tertuang dalam Al-Qur'an surat Al-Baqarah ayat 256, yang artinya sebagai berikut: "Tidak ada paksaan untuk (memasuki) agama (Islam), sesungguhnya telah jelas jalan yang benar dan jalan yang sesat" Adanya kata-kata tidak ada paksaan ini, berarti Islam menghendaki dalam perbuatan apapun harus didasarkan oleh kebebasan untuk bertindak sepanjang itu benar dan tidak bertentangan dengan nilai-nilai syariah.; (b) Al-Musawah (Persamaan dan Kesetaraan) Asas ini mengandung pengertian bahwa para pihak mempunyai kedudukan (bargaining position) yang sama, sehingga dalam 
menentukan trem and condition dari suatu akad/perjanjian setiap pihak mempunyai kesetaraan atau kedudukan yang seimbang.

Dasar hukum mengenai asas persamaan ini tertuang di dalam ketentuan $\mathrm{Al}$ Qur'an surah Al-Hujurat ayat 13 yang artinya sebagai berikut: "Sesungguhnya orang yang paling mulia diantara kamu di sisi Allah ialah orang yang paling bertaqwa di antara kamu. Sesungguhnya Allah Maha Mengetahui lagi Maha Mengenal”. Dari ketentuan tersebut, Islam menunjukan bahwa semua orang mempunyai kedudukan yang sama di depan hukum (equality before the law), sedangkan yang membedakan kedudukan antara orang satu dengan yang lainnya di sisi Allah adalah derajat ketaqwaannya.; (c) Al-'Adalah (Keadilan) Pelaksanaan asas ini dalam suatu perjanjian/akad menurut para pihak untuk melakukan yang benar dalam pengungkapan kehendak dan keadaan, memenuhi semua kewajibannya. Perjanjian harus senantiasa mendatangkan keuntungan yang adil dan seimbang, serta tidak boleh mendatangkan kerugian bagi salah satu pihak.; (d) Al-Ridha (Kerelaan) Asas ini menyatakan bahwa segala transaksi yang dilakukan harus atas dasar kerelaan antara masing-masing pihak, harus didasarkan pada kesepakatan bebas dari para pihak dan tidak boleh ada unsur paksaan, tekanan, penipuan dan mis-statemen. Dasar hukum adanya asas kerelaan dalam pembuatan perjanjian dapat dibaca dalam Al-Qur'an Surat An-Nisa ayat 29, yang artinya sebagai berikut: "Hai orang-orang yang beriman janganlah kamu saling memakan harta sesamamu dengan jalan yang batil, kecuali dengan jalan perniagaan yang berlaku suka-sama suka di antara kamu... " Kata "suka sama suka" menunjukan bahwa dalam hal membuat perjanjian, khususnya di lapangan perniagaan harus senantiasa didasarkan pada asas kerelaan atau kesepakatan para pihak secara bebas.; (e) Ash-Shidiq (Kebenaran dan Kejujuran) Dalam Islam setiap orang dilarang melakukan kebohongan dan penipuan, karena dengan adanya penipuan/kebohongan sangat berpengaruh dalam keabsahan akad/perjanjian. Perjanjian yang didalamnya mengadung unsur penipuan/kebohongan, memberikan hak kepada pihak lain untuk menghentikan proses pelaksanaan perjanjian tersebut. 
Dasar hukum mengenai asas Ash-Shidi, terkandung dalam Al-Qur'an Surat Al-Ahzab ayat 70, yang artinya sebagai berikut: "Hai orang-orang yang beriman, bertakwalah kamu kepada Allah dan katakanlah perkataan yang benar" Bahwa setiap muslim wajib berkata-kata yang benar, lebih-lebih dalam melakukan perjanjian dengan pihak lain, sehingga faktor kepercayaan (trust) menjadi sesuatu yang esensial demi terlaksananya suatu perjanjian atau akad.; (f) Al-Kitabah (Tertulis) Bahwa setiap perjanjian hendaknya dibuat secara tertulis, lebih berkaitan demi kepentingan pembuktian jika dikemudian hari terjadi sengketa. Dalam Al-Qur'an surat $\mathrm{Al}$ Baqarah ayat 282-283 mengisyaratkan agar akad yang dilakukan benar-benar berada dalam kebaikan bagi semua pihak. Bahkan juga di dalam pembuatan perjanjian hendaknya juga disertai dengan adanya saksi-saksi (syahadah), rahn (gadai, untuk kasus tertentu) dan prinsip tanggung jawab individu.

Akad Pembiayaan Murabahah dalam Perbankan Syariah, Secara etimologis perjanjian dalam Bahasa Arab diistilahkan dengan Mu'ahadah Ittifa, atau Akad. Dalam Bahasa Indonesia dikenal dengan kontrak, perjanjian atau persetujuan yang artinya adalah suatu perbuatan di mana seseorang atau lebih mengikatkan dirinya terhadap seseorang lain atau lebih. Akad menurut Ahmad Azhar Basyir yang dikutip oleh Abdul Gofur Ansori, memberikan defenisi akad sebagai berikut, akad adalah suatu perikatan antara ijab dan kabul dengan cara yang dibenarkan syarak yang menetapkan adanya akibat-akibat hukum pada obyeknya. Ijab adalah pernyataan pihak pertama mengenai isi perikatan yang diinginkan, sedangkan kabul adalah pernyataan pihak kedua untuk menerimanya.

Pada hakikatnya setiap akad yang dibuat oleh para pihak haruslah berdasarkan atas kebebasan berkontrak serta kerelaan para pihak dalam membuat akad tersebut. Tidak terkecuali pada pembiayaan murabahah akad yang dibuat harulah berlandaskan prinsip kerelaan para pihak. Pembiayaan dengan akad murabahah berdasarkan Undang-undang No 21 Tahun 2008 tentang Perbankan Syariah memberikan definisi tentang murabaha dalam Penjelasan Pasal 19 ayat (1) huruf d 
tersebut, yang dimaksud dengan akad murabahah adalah akad pembiayaan suatu barang dengan dengan menegaskan harga belinya kepada pembeli dan pembeli membayarnya dengan harga yang lebih sebagai keuntungan yang disepakati. Penjelasan murabahah berdasarkan pasal di atas masih terlalu sempit seolah-olah murabahah hanya merupakan perjanjian jual-beli barang biasa tanpa melibatkan suatu lembaga pembiayaan atau lembaga keuangan. Sehingga menurut Sutan Remy Sjahdeini murabahah adalah suatu jasa atau produk pembiayaan yang diberikan oleh suatu lembaga pembiayaan berdasarkan Prinsip syariah (lembaga pembiayan syariah) kepada nasabahnya yang membutuhkan dan memesan suatu barang tertentu.

Murabahah merupakan produk pembiayaan perbankan syariah yang dilakukan dengan mengambil bentuk transaksi jual-beli (bai' dan sale). Namun murabahah bukan transaksi jual beli biasa antara satu pembeli dan satu penjual saja sebagaimana yang kita kenal di dalam dunia bisnis perdagangan diluar perbankan syariah. Pada perjanjian murabahah, bank membiayai pembelian barang atau aset yang dibutuhkan oleh nasabahnya dengan membeli terlebih dahulu barang atau aset yang dibutuhkan oleh nasabahnya dengan membeli terlebih dahulu barang itu dari pemasok barang dan setelah kepemilikan barang itu secara yuridis berada ditangan bank, kemudian bank tersebut menjualnya kepada nasabah dengan menambahkan suatu mark-up/ margin yang ditambahkan ke atas harga beli bank tersebut. Dengan kata lain, penjualan barang oleh bank kepada nasabah dilakukan atas dasar cost-plus profit.

Menurut Tarek al-Diwany, sebagaimana dikutip oleh Khir et al., murabahah adalah suatu bentuk jual beli berdasarkan kepercayaan (trust sale) karena pembeli harus percaya bahwa penjual akan mengungkapkan harga beli yang sebenarnya (true cost). Ketidaktauhan dan kurang pahamnya tentang kondisi pasar serta kurangnya kepercayaan pembeli terhadap penjual dengan berkurang tingkat kejujuran penjual maka pembeli menghubungi lembaga pembiayaan untuk membelikan barang dengan spesifikasi yang telah disepakati. Sehingga peran perbankan selaku lembaga yang 
ditunjuk untuk menyediakan barang tersebut mengguakan akad murabahah. Mark up/ margin yang didapatkan oleh bank merupakan kesepakatan para pihak. Menurut Shanmugam "keuntungan yang diperoleh dari suatu barang merupakan imbalan atas tanggung jawab penjual terhadap kemungkinan hilangnya barang itu selama dalam penguasaannya dan belum beralih kepemilikannya kepada pembeli. Pada saat transaksi murabahah, bank memikul risiko yang mungkin timbul atas pembelian suatu barang selama barang itu dalam kekuasaannya sebelum akhirnya dijual kepada pihak lain dengan menambahkan suatu keuntungan (mark-up). Keuntungan ini dianggap merupakan imbalan atas kemungkinan risiko yang menjadi tanggung jawab bank, baik berupa kehilangan atau kerusakan, sebelum barang itu akhirnya dijual kepada nasabah. Dengan kata lain, bank yang terlibat dalam pembelian dan penjualan memikul risiko tertentu. oleh karena itu, adalah sudah sepatutnya apabila bank memperoleh keuntungan atas transaksi penjualan yang dilakukannya kepada nasabah.

Pembiayaan Murabahah diatur dalam Fatwa DSN No. 04/DSN-MUI/IV/2000 pada tanggal 1 April 2000 yang intinya menyatakan bahwa dalam rangka membatu masyarakat guna melangsungkan dan meningkatkan kesejahteraan dan berbagai kegiatan, bank syariah perlu memiliki fasilitas murabahah bagi yang memerlukannya, yaitu menjual suatu barang dengan menegaskan harga belinya kepada pembayarannya dengan harga yang lebih sebagai laba.

Ketentuan tentang pembiayaan murabahah yang tercantum dalam Fatwa DSN No. 04/DSN-MUI/IV/2000 adalah sebagai berikut; (1) Ketentuan Umum Murabahah; (a) Bank dan nasabah harus melakukan akad murabahah yang bebas riba.; (b) Barang yang diperjualbelikan tidak diharamkan oleh syariat Islam.; (c) Bank membiayai sebagian atau seluruhnya harga pembelian barang yang telah disepakati kualifikasinya.; (d) Bank membeli barang yang diperlukan nasabah atas nama bank sendiri dan pembelian itu harus sah dan bebas riba.; (e) Bank harus menyampaikan semua hal yang berkaitan dengan pembelian, misalnya jika pembelian dilakukan secara hutang.; (f) Bank kemudian menjual barang tersebut kepada nasabah 
(pemesan) dengan harga jual senilai harga beli plus keuntungannya. Dalam kaintan ini Bank harus memberikan secara jujur harga pokok barang barang kepada nasabah berikut biaya yang diperlukan.; (g) Nasabah membayar harga barang yang telah disepakati tersebut pada jangka waktu tertentu yang telah disepakati.; (h) Untuk mencegah terjadinya penyalahgunaan atau kerusakan akad tersebut, pihak bank dapat mengadakan perjanjian khusus dengan nasabah.; (i) Jika bank hendak mewakilkan kepada nasabah untuk membeli barang dari pihak ketiga, akad jual beli murabahah harus dilakukan setelah barang, secara prinsip, menjadi milik bank.; (2) Ketentuan Murabahah kepada Nasabah.; (a) Nasabah mengajukan permohonan dan perjanjian pembelian suatu barang atau asset kepada bank.; (b) Jika bank menerima permohonan tersebut, ia harus membeli terlebih dahulu asset yang dipesannya secara sah dengan pedagang.; (c) Bank kemudian menawarkan asset tersebut kepada nasabah dan nasabah harus menerima (membeli)-nya sesuai dengan perjanjian yang telah disepakatinya, karena secara hukum perjanjian itu mengikat, kemudian kedua belah pihak harus membuat kontrak jual beli.; (d) Dalam jula beli ini bank dibolehkan meminta nasabah untuk membayar uang muka saat menandatangani kesepakatan awal pemesanan.; (e) Jika nasabah kemudian menolak membeli barang tersebut, biaya riil bank harus dibayar dari uang muka tersebut.; (f) Jika nilai uang muka kurang dari kerugian yang harus ditanggung oleh bank, bank dapat meminta kembali sisa kerugiannya kepada nasabah. Jika uang muka memakai kontrak 'urbun' sebagai alternatif dari uang muka, maka: Jika nasabah memutuskan untuk membeli barang tersebut, ia tinggal membayar sisa harga. Jika nasabah batal membeli, uang muka menjadi milik bank maksimal sebesar kerugian yang ditanggung oleh bank akibat pembatalan tersebut; dan jika uang muka tidak mencukupi, nasabah wajib melunasi kekurangannya.; (g) Jaminan dalam murabahah diperbolehkan, agar nasabah serius dengan pesanannya. Di sini bank dapat meminta nasabah untuk menyediakan jaminan yang dapat dipegang.; (h) Hutang dalam murabahah secara prinsip penyelesaiannya tidak ada kaitannnya dengan transaksi lain yang dilakukan nasabah dengan pihak 
ketiga atas barang tersebut. Jika nasabah menjual kembali barang tersebut dengan keuntungan atau kerugian, ia tetap berkewajiban untuk menyelesaikan hutang kepada bank. Jika nasabah menjual barang tersebut sebelum masa ansuran berakhir, ia tidak wajib segera melunasi seluruh angsurannya. Kemudian jika penjualan barang tersebut menyebabkan kerugian, nasabah harus tetap menyelesaikan hutangnya sesuai kesepakatan awal. Ia tidak boleh memperlambat pembayaran angsuran atau meminta kerugian itu diperhitungkan.; (3) Penundaan pembayaran dalam murabahah Bahwa nasabah yang memiliki kemampuan tidak dibenarkan menunda penyelesaian hutangnya. Jika nasabah menunda-nunda pembayaran dengan sengaja, atau jika salah satu pihak menunaikan kewajibannya, maka penyelesaian dilakukan melalui badan Arbitrase Syariah setelah mencapai kesepakatan melalui musyawarah.; (4) Bangkrut dalam murabahah. Jika nasabah telah dinyatakan pailit dan gagal menyelesaikan hutangnya, bank harus menunda tagihan hutang sampai ia menjadi sanggup kembali, atau berdasarkan kesepakatan.

Dalam kegiatan penyaluran dana dalam bentuk pembiayaan atas dasar Akad Murabahah berlaku persyaratan paling kurang sebagai berikut; (A) Bank bertindak sebagai pihak penyedia dana dalam rangka membelikan barang terkait dengan kegiatan transaksi murabahah dengan nasabah sebagai pihak pembeli barang; (B) Barang adalah obyek jual beli yang diketahui secara jelas kuantitas, kualitas, harga perolehan dan spesifikasinya; (C) Bank wajib menjelaskan kepada nasabah mengenai karakteristik produk pembiayaan atas dasar Akad murabahah, serta hak dan kewajiban nasabah sebagaimana diatur dalam ketentuan Bank Indonesia mengenai transparansi informasi produk Bank dan Penggunaan data pribadi nasabah; (D) Bank wajib melakukan analisis atas permohonan pembiayaan atas dasar Akad Murabahah dari nasabah yang antara lain meliputi aspek personal berupa analisi atas karakter (Character) dan/atau aspek usaha antara lain meliputi analisis kapasitas usaha (Capacity), keuangan (Capital) dan/atau prospek usaha (Condition).; (E) Bank dapat membiayai sebagian atau seluruh harga pembelian barang yang telah disepakati 
kualifikasinya; (F) Bank wajib menyediakan dana untuk merealisasikan penyediaan barang yang dipesan nasabah; (G) Kesepakatan atas marjin ditentukan hanya satu kali pada awal pembiayaan atas dasar Murabahah dan tidak berubah selama periode pembiayaan; (H) Bank dan nasabah wajib menuangkan kesepatan dalam bentuk perjanjian tertulis berupa Akad Pembiayaan atas dasar Murabahah; dan; (I) Jangka waktu pembayaran harga barang oleh nasabah kepada Bank ditentukan berdasarkan kesepakatan Bank dan nasabah.

\section{Analisis Akad Murabahah dengan Menggunakan Asas Ar-Ridha dalam} Perbankan Syariah

Akad Murabahah dari Bank Mandiri Syariah Pertama, Harga Jual AlMurabahah dan juga dari Penggunaannya: 1. Nasabah dengan ini berjanji dan mengikatkan diri kepada bank untuk membayar harga jual barang atau hutang murabahah, yang terdiri dari Harga Beli + Keuntungan Maksimum $=$ Jumlah atau Harga Jual Maksimum; 2. Setiap realisasi jual-beli al-murabahah secara bertahap maupun sekaligus, dipergunakan khusus untuk pembelian.

Kedua, Jual-Beli dan Hutang Murabahah. Dengan tetap memperhatikan dan menaati ketentuan tentang jual-beli barang secara murabahah, bank berjanji dan dengan ini mengikatkan diri untuk melaksanakan jual-beli barang dengan pihak nasabah dengan cara piutang murabahah, setelah pihak nasabah memenuhi seluruh prasyarat sebagai berikut: 1. Nasabah telah menyerahkan kepada bank seluruh dokumen nasabah, termasuk dan tidak terbatas pada dokumen-dokumen jaminan yang berkaitan dengan akad ini; 2 . nasabah telah menandatangani akad ini serta akad pengikatan jaminannya serta menyerahkan bukti-bukti tentang kepemilikan atau hak lain atas barang jaminannya; 3. Nasabah telah membuat dan juga menandatangani tanda bukti penerimaan uang, dan meyerahkannya kepada bank; Terhadap pelaksanaan jual beli secara murabahah, nasabah wajib menyerahkan aksep atau Surat Sanggup membayar kepada bank. 
Ketiga, Jangka Waktu dan juga Cara Pembayaran. Nasabah berjanji dan dengan ini akan mengikatkan diri untuk membayar kembali jumlah keseluruhan kewajibannya pada bank dalam jangka waktu yang terhitung dari tanggal sekian sampai dengan tanggal sekian dengan cara mengangsur pada tiap-tiap bulan sesuai dengan jadwal angsuran yang telah ditetapkan dalam Surat Sanggup Membayar, yang merupakan bagian yang mana tidak terpisahkan dari akad ini: 1. Dalam hal terjadi keterlambatan pembayaran oleh nasabah kepada bank, maka nasabah berjanji dan dengan ini mengikatkan diri untuk membayar biaya administrasi sebesar kerugian yang dialami oleh bank dengan perhitungan sejak saat kewajiban pembayaran tersebut telah jatuh tempo sampai dengan tanggal dilaksanakannya suatu pembayaran kembali; 2. Setiap pembayaran oleh nasabah kepada bank lebih dahulu digunakan untuk melunasi biaya administrasi dan biaya lainnya berdasarkan akad ini dan sisanya baru dihitung sebagai pembayaran angsuran/pelunasan atas harga jual bank sebagai penjual; 3. Dalam hal jatuh tempo pembayaran kembali pembiayaan jatuh bertepatan dengan bukan pada hari kerja bank, maka nasabah berjanji dan dengan ini mengikatkan diri untuk melakukan pembayaran 1 (satu) hari sebelum hari yang bukan merupakan hari kerja tersebut.

Keempat, Jaminan. Untuk menjamin tertibnya pembayaran kembali atau pelunasan pembiayaan dan margin keuntungan tepat pada waktu yang telah disepakati kedua belah pihak berdasarkan akad ini, maka nasabah berjanji dan dengan ini mengikatkan diri untuk menyerahkan jaminan dan juga membuat pengikatan jaminan kepada bank sesuai ketentuan peraturan perundang-undangan yang berlaku, yang merupakan bagian yang tidak terpisahkan dari akad ini. Jenis barang jaminan yang diserahkan adalah berupa ....

Berdasarkan akad murabahah di atas maka dapat diambil suatu kesimpulan bahwa murabahah terjadi apabila 1. Adanya seorang nasabah yang membeli suatu barang yang disediakan oleh pihak bank, 2. Bank menyediakan barang sesaui harga awalnya dan menjual dengan harga tambahan berupa mark-up/margin yang telah 
disepakati, 3. Nasabah membayar angsuran kepada Bank sekaligus marginnya, 4. Nasabah memberikan suatu barang atau hal lain yang dapat menjadi jaminan buat Bank.

Akad sebagai cerminan telah terjadinya hubungan dan kesepakatan antara pihak bank dan nasabah harus mencerminkan asas-asas akad yang tertuang dalam perundang-undangan dan hukum muamalah Islam. Berawal dari akad inilah yang membedakan bank syariah dan bank konvensional karena akad yang diterapkan diperbankan syariah dan lembaga keuangan syariah non bank lainnya memiliki konsekuensi duniawi dan ukhrawi karena dilakukan berdasarkan hukum Islam. Dalam penerapan pola hubungan akad inilah sudah seharusnya tidak terdapat penyimpangan-penyimpangan dari kesepakatan yang telah dibuat oleh kedua belah pihak karena masing-masing menyadari akan pertanggungjawaban dari akad tersebut. Prinsip yang digunakan dalam pembiayaan yang berbasis syariah yakni kemitraan yang mengutamakan hubungan yang harmonis antara para pihak.

Dalam bentuk jumlah pembiayaan juga disebutkan secara jelas dan detil pada kedua belah pihak bank yang menyebutkan berapa harga pokok, margin keuntungan dan jangka waktu tersebut jelas. Hanya saja yang menjadi permasalahan terlihat pada prosedur sebelum akad dibuat terkait dengan hak dari bank untuk menentukan margin keuntungan dan berkewajiban untuk memberikan kesempatan bagi nasabah untuk melakukan negosiasi (tawar menawar) terhadap kesepakatan margin keuntungan, bagi pihak nasabah mempunyai hak untuk menentukan lama atau jangka waktu pembiayaan dan berkewajiban untuk melakukan pembayaran sesuai dengan kesepakatan yang dilakukan dengan pihak bank. Dalam kondisi umum yang dilakukan pihak bank masih menggunakan bentuk dari kontrak baku yang dibuat secara sepihak, hal ini tidak menjadi masalah ketika sesuai dengan ketentuan yang tertuang dalam Pasal 18 Undang-undang Nomor 8 Tahun 1999 tentang Perlindungan Konsumen yang di dalamnya mengatur tentang pihak pelaku usaha dalam hal ini Bank Syari'ah diperbolehkan untuk membuat klausula baku, selama tidak 
bertentangan dengan Pasal tersebut. Selain itu dalam bentuk etika bisnis Islam memperbolehkan menggunakan standar kontrak selama tidak merugikan salah satu pihak dan bermanfaat bagi kemaslahatan umat.

Dalam asas perjanjian menurut hukum Islam sendiri mengatur tentang beberapa asas yang antara lain di dalamnya adalah Al-Musawah (kesetaraan) atau keseimbangan yang berarti kedua belah pihak yang mengikatkan diri dalam akad pembiayaan tersebut mempunyai hak dan kewajiban yang sama dalam menentukan bargaining position dan terms and condition dalam klausul-klausul yang dibuat. Hal ini menampakkan secara jelas bahwa sebagai negara yang berdasarkan atas hukum kita harus menjunjung tinggi nilai-nilai keseimbangan di mata hukum. Sebagai bentuk pengawasan dalam melaksanakan kewenangannya untuk Bank Syari'ah Majelis Ulama Indonesia melalui Dewan Syari'ah Nasional harus melakukan pengawasan terhadap terlaksananya kesetaraan atau keseimbangan (asas $A l$ Musawah) dalam praktik perbankan Syari'ah. Asas Al-Musawah ini sebenarnya menjadi dasar untuk asas yang lain dapat berjalan sebagaimana mestinya sesuai ketentuan seperti asas Al Adalah (keadilan) yang sesuai dengan proporsional masingmasing pihak. Adil di sini tidak berarti kesamaan dalam mendapatkan bagian (50:50), tapi bisa saja bentuk dari adil di sini adalah (60:40) tergantung pada hak dan kewajiban yang sesuai proporsinya. Kemudian asas Ar Ridha yang berarti kerelaan yang mempunyai pengertian dalam pembuatan kesepakatan tidak boleh ada pihak yang merasa terpaksa dalam menjalani isi klausul-klausul tersebut. Prinsip Ar Ridha memberikan kerelaan kepada kedua belah pihak untuk membuat dan menyetujui suatu perjanjian sehingga memberikan kebebasan kepada pihak nasabah untuk menyetujui atau menolak perjanjian tersebut. Perjanjian baku yang disediakan oleh pihak bank merupakan cara untuk mempermudah proses pelayanan kepada nasabah dan menurut peraturan yang berlaku hal tersebut diperbolehkan. Selama para pihak dalam hal ini nasabah masih diberikan kebebasan untuk menyetujui atau menolak (take it or leave it) maka prinsip Ar-Ridha berlaku. 
Sesuai ketentuan yang berlaku dan mengatur tentang margin keuntungan yang akan menentukan jumlah pembiayaan adalah berdasarkan pada kemampuan nasabah dalam melakukan pembayaran sesuai dengan jangka waktu yang disepakati. Namun hal ini menjadi tidak berlaku disaat pihak Bank Syari'ah masih memperhitungkan berdasar pada suku bunga Bank Indonesia yang secara jelas bertentangan dengan larangan dalam hukum Islam yakni pembebanan bunga adalah Riba dan hukumnya Haram. Hal ini terlihat dalam bentuk perhitungan dalam menentukan margin keuntungan yang digunakan dalam Bank BNI Syari'ah yang menggunakan nilai 40\% dari suku bunga bank Indonesia dengan dasar untuk menjaga nilai fluktuatif (naik turunnya) kondisi perekonomian di Indonesia, demikian pula yang dilakukan oleh BSM yang menggunakan kurang lebih 55\% dari suku bunga bank Indonesia dengan sistem bunga Flat untuk menentukan besarnya Margin keuntungan, angka yang digunakan ini sebagai dalih untuk melakukan Mark Up yang tidak sesuai dengan prinsip hukum Islam, karena hal ini jelas akan memberatkan pihak nasabah terlebih jika tidak diberikan kesempatan oleh pihak bank untuk melakukan tawar menawar dalam menentukan angka margin keuntungan ini. Terlihat secara jelas bentuk ketidakseimbangan atau kesetaraan tidak terwujud.

\section{SIMPULAN}

Akad merupakan cerminan telah terjadinya hubungan dan kesepakatan antara pihak bank dan pihak nasabah untuk melakukan suatu kegiatan ekonomi. Kegiatan ekonomi dalam prinsip syariah menggunakan prinsip kemitraan sehingga lebih mengutamakan hubungan yang harmonis antara kedua belah pihak. Akad yang konsekuensi pertanggungjawabannya tidak hanya didunia tetapi juga diakhirat sehingga mempunyai akibat yang sangat berat. Pelaksanaan akad murabahah dalam melakukan kegiatan pembiayaan untuk pembelian sutau obyek tertentu dengan disepakati para pihak berserta mark-up/margin yang telah disepakati. Yang mana untuk memudahkan transaksi bank membuat suatu kontrak baku sehingga pihak bank tinggal membubuhkan tanda-tangan untuk persetujuan kontrak tersebut. Telah menggambarakan prinsip syariah yaitu ar-ridha karena diberikan keleluasaan pihak nasabah untuk menyetujui atau menolak perjanjian tersebut atau adanya pilihan bebas kepada pihak nasabah. 


\section{DAFTAR PUSTAKA}

Abdul Ghofur Anshori, "Sejarah Perkembangan Hukum Perbankan Syari'ah Di Indonesia Dan Implikasi Bagi Praktek Perbankan Syari'ah" Dalam La Riba, Jurnal Ekonomi Islam, Volume II, Nomor 2 (Desember 2008),

Abdul Ghofur Anshori, 2009, Perbankan Syariah Di Indonesia, Gadjah Mada University Press, Yogyakarta

Deloitte, "Murabahah Anuitas Perspektif Baru Lembaga Keuangan Syariah", Http:// Www. Deloitte.Com/Id. Diakses 20 September 2013.

Fathurahman Djamil (Et Al), 2001, Hukum Perjanjian Syariah Dalam Kompilasi Hukum Perikatan, PT. Citra Aditya Bakti, Bandung,

Hermansyah, 2005, Hukum Perbankan Nasional Indonesia, Edisi Revisi, Cetakan Ke-3, Kencana Prenada Media Group, Jakarta,

Karim Adiwarman A, 2003, Bank Islam, Analisis Fiqih Dan Keuangan, III T, Jakarta, M. Ariff, "Islamic Banking", Asian-Pasific Economic Literature, Vol. 2, No. 2. September 1988

M. Syafii Antoni, Bank Syariah (Islamic Banking), Dari Teori Ke Praktik, Jakarta, Gema Insani Dan Tazkia Cendekia

M. Yazid Bin Zul Kepli, "Islamic Finance In Hong Kong,” Hong Kong Law Journal, Volume. 42, Nomor 3 Tahun 2012,

Nur Sanita Nasution, "Pajak Berganda Menghambat Perbankan Syariah”, Jurnal Ekonomi Syariah Muamalah, Vol. 6 Mei 2009,

Penjelasan Umum Undang-Undang Republik Indonesia Nomor 10 Tahun 1998 Tentang Perbankan

Penjelasan Umum Atas Peraturan Bank Indonesia Nomor: 11/3/PBI/2009 Tentang Bank Umum Syariah Penjelasan Fatwa No. 04/DSN-MUI/IV/2000 Tentang Murabahah

Sutan Remy Sjahdeini, 2014, Perbankan Syariah, Kencana Prenadamedia Group, Jakarta

Syamsul Anwar, 2007, Studi Hukum Islam Kontemporer, RM. Books, Jakarta

Yayasan Penyelenggaraan Penterjemahan Al-Qur'an, 1989, Al-Qur'an Dan Terjemahannya, CV. Toha Putra, Semarang, 